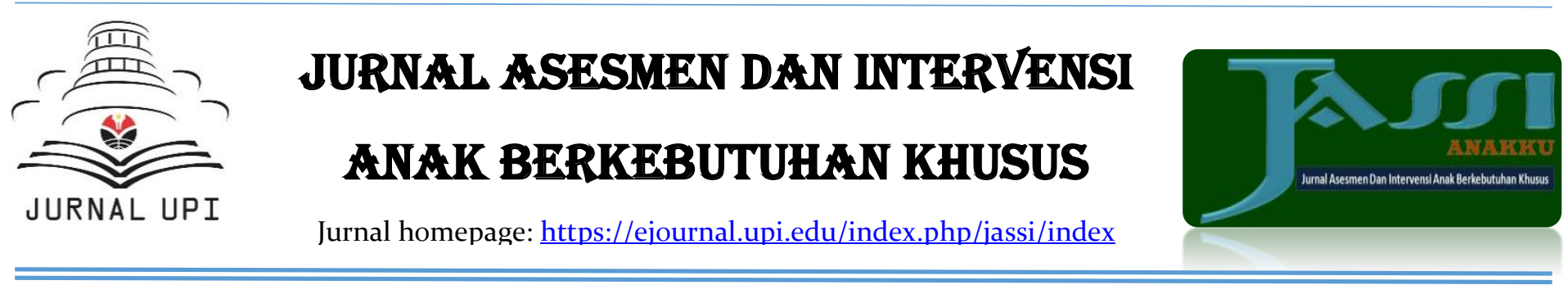

\title{
Analysis of the Difficulties of Parents in Accompanying Children with Special Needs at the Elementary School Level during Online Learning in the Covid-19 Pandemic
}

\author{
Ahmad Rizki Fauzi ${ }^{1 *}$, Rina Maryanti ${ }^{2}$, Asep Rudi Irawan \\ ${ }^{1}$ Departemen Psikoogi, Universitas Pendidikan Indoensia, Indonesia \\ ${ }^{2}$ Departemen Pendidikan Khusus, Universitas Pendidikan Indonesia, Indonesia \\ ${ }^{3}$ School of Human Sciences, University of Tsukuba, Japan \\ Correspondence: E-mail: maryanti.rinai@upi.edu
}

\section{A B S T R A C T S}

The role of parents is needed when students with special needs study from home. However, when accompanying children to learn online, parents find it difficult due to various factors. Here, the purpose of this study is to analyze how difficult it is for parents to accompany elementary school children with special needs during online learning. The research method used is descriptive qualitative with the population and the research sample are parents of elementary school students as many as 20 people. The data collection technique used in this research is a survey in the form of a questionnaire, observation notes, and documentation. The results of this study indicate that in general, the obstacles for parents in assisting children with special needs to study online at home during the Covid-19 pandemic are the lack of understanding of the material by parents, the difficulty of parents in growing their children's interest in learning, not having enough time to accompany their children because they have to work, parents are impatient in accompanying children while studying at home, parents have difficulties in operating gadgets, and obstacles related to the internet service coverage.

\begin{tabular}{l} 
A R T I C L E I N F O \\
\hline Article History: \\
Received 20 Oct 2020 \\
Revised 20 Nov 2020 \\
Accepted 29 Nov 2020 \\
Available online 01 Dec 2020 \\
\hline Keyword: \\
Parental Difficulties, \\
Children, \\
Special Needs, \\
Online Learning, \\
Pandemic Period,
\end{tabular}




\section{INTRODUCTION}

Many sectors of life have been affected as a result of the pandemic caused by the outbreak of the Covid-19 virus. One of them is in the education sector, where there has been a big change in it that has never happened before, namely the transition of learning activities that were initially carried out face-to-face in schools, now changing modes to online. This change in learning activities has been determined by the government through the Circular Letter of the Minister of Education and Culture Number 36962/MPK.A/HK/2020 which contains that learning must be done online so that Corona Virus Disease (Covid-19) can be prevented from spreading (Karnawati \& Mardiharto, 2020).

Various parties, both teachers, parents, and student with special needs are also required to be able to adapt to these sudden changes. On the other hand, the choice of online learning alternatives is due to the current industrial revolution 4.0. has grown very rapidly. This is certainly very supportive of the implementation of online learning from home, because online learning is learning that eliminates time and distance with the help of internet-based digital platforms that are able to support learning to be carried out without any physical interaction between educators and student with special needs (Putra \& Irwansyah, 2020). For this reason, the current technological sophistication is expected to be able to support these online activities. However, at the elementary school (SD) level during this online learning process, all elements of education are of course required to be able to provide learning facilities so that they remain active even though it is done without face-toface meetings. Because, student with special needs who originally studied at school with teachers now have to learn from home (study from home) which of course requires an important role from parents. The role of parents is very important in helping their children with special needs in the learning process at home, such as (1) parents' guide their children with special needs in using the technology used when studying; (2) parents as facilities and infrastructure facilitators; (3) parents as motivators to provide enthusiasm, motivation, and support in carrying out learning so as to obtain good achievements; (4) parents as regulators or directors (Ardiansyah \& Arda, 2020). Thus, the role of parents in achieving online learning goals while studying at home is very important (Wardani \& Ayriza, 2020).

However, based on observations that have been made, conditions in the field currently show that online learning or learning carried out at home with parental guidance for children with special needs at the elementary school age level has several difficulties and obstacles, so that not a few parents ask the schools to be able to immediately carry out face-to-face learning. This is also supported by several studies that discuss the analysis of parental constraints in assisting children to learn from home conducted by researchers. Research conducted by Wardani \& Ayriza (2020) regarding the analysis of parental constraints in assisting children to study at home during the Covid-19 pandemic, Iftitah \& Anawaty (2020) regarding the role of parents in accompanying children at home during the Covid-19 pandemic, while Harahap et. al., (2021) the problems of early childhood online and offline learning for teachers and parents during the Covid 19 pandemic. However, until now there has been no research that discusses the difficulties of parents in accompanying children at the elementary level while carrying out online learning in the time of the Covid19 pandemic. So different from previous research, this study focuses on parents of children with special needs of primary school age.

Therefore, a research study on the analysis of the difficulties of parents in assisting children with special needs at the elementary school level during online learning during the COVID-19 pandemic in this study is very important to do in understanding how the real

DOI: http://dx.doi.org/10. 17509/xxxxt.vxix p- ISSN 1412-9337 e- ISSN 2776-8783 
obstacles experienced by parents in accompanying their children studying at home replaces the role of the teacher during the Covid-19 pandemic with online learning methods and how to handle the obstacles experienced by parents in assisting children to study at home during the Covid-19 pandemic.

\section{METHODS}

The method used in this research is descriptive qualitative. This research wants to see how the challenges for parents in accompanying children with special needs to learn online and how parents overcome them. The instruments used in this research are survey in the form of questionnaires, observation notes, and documentation.

The population and sample of this study were parents of 20 student with special needs of Elementary School. Data collection techniques used in this study are survey instruments in the form of questionnaires/questionnaires, question forms, observation notes, and documentation. Survey In the form of this questionnaire, it is loaded into a Google form and distributed through the Whatsapp group. Before taking data, the researcher first asked the respondent's willingness to participate in this study. After receiving the approval, the researcher then distributed the questionnaire in the form of a google form to the respondents. After that, respondents were asked to fill out a questionnaire form questions for data entry which consists of several parts.

The research instrument used is list of questions organized by adaptation of the student with special needs parent instrument regarding the learning readiness survey during the pandemic Covid-19 compiled by the Ministry of Education and Culture research questions for parents accompanying children with special needs of Elementary School compiled by other researchers which consists of 24 items and is divided into two parts. The first part contains a brief description of the demographic data of the respondents which includes name, age, gender, last education, occupation, monthly income, address, and telephone number. The second part is an entry regarding the assistance of parents to children with special needs in online learning, and the third part is the difficulty of assisting parents to their children with special needs in online learning. The questions were asked to find out the parents' responses the assistance and difficulties of parents to children with special needs in online learning during the Covid-19 pandemic are as follows in Tables $\mathbf{1}$ and $\mathbf{2}$.

\section{RESULTS AND DISCUSSION}

This research is a descriptive type of research to describe parent response on the assistance and difficulties of parents to children with special needs in online learning during the Covid-19 pandemic, so the analysis used also uses descriptive techniques. The data is processed according to the facts as they are without using advanced statistical techniques. The data processing and analysis uses a description with the help of a table, the percentage in the pie chart, as well as the answers obtained. This was taken because the question in the questionnaire regarding the Difficulty of Assisting Children with special needs in Online Learning uses the Gutman scale which only asks for each indicator in two possible answers, Yes or No. The results of the analysis are given attributes using the following criteria: score 80\%-100\% (very high), 70\%-79.9\% (High), 60\%-69.9\% (Medium), 50\%-59.9\% (less), and less than $50 \%$ (very low). 
Table 1. Question items to know parents' responses to parental assistance to children with special needs in online learning during the covid-19 pandemic

\begin{tabular}{l} 
No \\
\hline 1 Do you have more than one child studying in elementary school? \\
2 During the learning process from home, do parents/guardians accompany children with special needs? \\
If not accompanied, what is the reason? (can choose more than one) \\
a. Both parents/guardians work \\
b. One parent/guardian works \\
c. Have other responsibilities at home \\
d. Not mastering children with special needs material \\
e. There are already other family members accompanying \\
f. Children with special needs are independent enough and do not need assistance \\
Who will accompany your child to study at home? \\
a. Older brother \\
b. Other Family Members \\
c. Caregiver/household assistant (ART) \\
d. Tutor \\
e. There is not any
\end{tabular}

Do schools/teachers communicate with parents/guardians in monitoring the child's learning process from home?

6 What things do the school/teacher ask you in order to monitor the child's learning process from home? (can choose more than one)
a. Children with special needs Learning Development
b. Children with special needs Learning Motivation
c. Children with special needs Learning Method
d. Children with special needs Learning Facilities and Resources

What do you do to monitor your child's learning activities from home? (can choose more than one)
a. Completing the completion of tasks that children with special needs do
b. Checking the children with special needs work
c. Checking children with special needs understanding of learning materials
d. Communicating with children with special needs regarding learning difficulties
e. Consulting with teachers regarding children with special needs learning barriers
f. Not monitoring children with special needs learning activities

What electronic devices do you have at home that can support online learning? (can choose more than one)
a. Mobile (HP)
e. Laptops
b. Wifi
f. Computer
c. Television
g. Camera
d. Radio
h. Cam Recorder

9 Does your child use their own cellphone when learning online?

10 What applications do you have on your mobile (HP)/laptop/computer to support online learning? (can choose more than one)
a. Whatsapp
e. Microsoft Excel (Ms Excel)
b. Telegram
f. Microsoft Powerpoint
c. Youtube
d. Microsoft Word (Ms Word)
g. Zoom Meeting
h. Google Meet

11 What do you think about the following learning from home process?
a. My child can understand the subject matter well during the learning process from home
b. My child can use learning devices well (laptops, cellphones, learning applications, etc.)
c. My child uses media and offline learning resources well (TV, radio, worksheets, printed teaching materials)
d. Environmental conditions at home support children with special needs learning concentration
e. The school provides adequate assistance to parents of student with special needs
f. Outside of an emergency situation like today, the process of learning from home like this can be applied in the future


Table 2. Question items to know parent's responses to the difficulties of mentoring children with special needs in online learning during the covid-19 pandemic

\begin{tabular}{|c|c|}
\hline No & Question \\
\hline 1 & $\begin{array}{l}\text { Do you find it difficult to accompany your child to learn online because they have to provide funds } \\
\text { to buy internet quota every day? }\end{array}$ \\
\hline 2 & $\begin{array}{l}\text { Are you disturbed when doing homework because you have to accompany your child to learn } \\
\text { online from home? }\end{array}$ \\
\hline 3 & $\begin{array}{l}\text { Do you find it difficult to accompany your child to learn online because the child learns at will not } \\
\text { according to school hours? }\end{array}$ \\
\hline 4 & $\begin{array}{l}\text { Are you having trouble accompanying your child to learn online because you don't have internet } \\
\text { access? }\end{array}$ \\
\hline 5 & $\begin{array}{l}\text { find it difficult to teach your child to use a laptop or cellphone (HP) to do the assignments } \\
\text { y the teacher? }\end{array}$ \\
\hline 6 & $\begin{array}{l}\text { It to teach children with special needs to learn online because sometimes } \\
\text { is interrupted/disconnected? }\end{array}$ \\
\hline 7 & $\begin{array}{l}\text { having a hard time teaching your kids to learn online because homework is being } \\
\text { ? }\end{array}$ \\
\hline 8 & $\begin{array}{l}\text { get stressed when you have difficulty understanding the assignments given by the } \\
\text { to children with special needs? }\end{array}$ \\
\hline 9 & $\begin{array}{l}\text { Are you sometimes emotional in accompanying your child to study because the child is not } \\
\text { disciplined in learning? }\end{array}$ \\
\hline 10 & $\begin{array}{l}\text { Do you prefer children with special needs to study at school because there is no burden or } \\
\text { obligation to accompany children with special needs to study? }\end{array}$ \\
\hline 11 & Do you prefer your child to study at home because you don't have to pay for transportation? \\
\hline 12 & mpany your child to study while doing other homework? \\
\hline 13 & Do you routinely accompany your child to learn online every day? \\
\hline
\end{tabular}

\subsection{Parental Assistance to Children with special needs in Online Learning}

The results of parental assistance response to children with special needs in online learning are shown in Table 3. As many as $30 \%$ of respondents stated that the number of children with special needs currently studying in elementary school is more than one person, while the rest answered no. The majority of respondents, $85 \%$, also accompany children with special needs to learn during the learning process from home. The majority of the variety of activities carried out by respondents in monitoring children with special needs learning activities from home is like helpingchecking the tasks done by the child (75\%), then followed by helping complete the completion of the task being done by the child (65\%), checking the child's understanding of the learning material (55\%), communicate with children with special needs regarding learning problems (45\%), as well as consulted with teachers regarding children with special needs learning barriers $(10 \%)$. The reason that reveals why respondents cannot accompany children with special needs during the learning process from home is because the majority of respondents, both parents/guardians are working $(30 \%)$, or one of them is working $(35 \%)$, while the other reason is stating that respondents have other responsibilities at home (20\%) and also have other family members accompanying them (5\%). In addition to parents/guardians, the majority of respondents $60 \%$ stated that other family members accompanied their children with special needs while studying from home, while others revealed that older siblings (35\%) and caregivers/household assistants (5\%) also accompanied their children with special needs. their children with special needs while studying from home. 
Although there are some respondents who cannot accompany their children with special needs when learning online from home, the majority of respondents, 95\%, stated that schools/teachers still help to communicate with parents/guardians in monitoring their children with special needs learning process from home. Meanwhile, things that are often asked by schools/teachers to respondents in order to monitor children with special needs learning process from home are such as about children with special needs learning development $(100 \%)$, and also about $15 \%$ of children with special needs motivation, methods, and learning facilities and resources.

During online learning as it is currently often done, of course, it requires adequate electronic devices. Respondents answered in a balanced way that their children with special needs used their own cellphones when learning online or using their cellphones, so all respondents (100\%) stated that they had cellphones (HP). However, apart from cell phones, respondents also stated that other electronic devices they have at home to support online learning are television (40\%), and wifi (5\%). The majority of applications found on mobile phones (HP)/laptops/computers owned by respondents to support online learning include the WhatsApp application (100\%), and followed by the use of other applications, such as Youtube (55\%), Zoom Meeting (35\%), Microsoft Word (10\%), as well as applications telegram, microsoft excel and microsoft power point (5\%).

In addition, the researcher also found out about the respondents opinions about the learning process from home based on the six statements that have been provided. In the first statement, "My child can understand the subject matter well during the learning process from home", as many as 12 respondents agreed with the statement, while 8 respondents stated otherwise. Then, in the second statement, "My child can use learning devices well (laptops, cellphones, learning applications, etc.)", as many as 14 respondents agreed with the statement, while 6 other respondents stated otherwise. The third statement which states that "My child uses media and offline learning resources well (TV, radio, worksheets, printed teaching materials)", 17 respondents agreed with the statement, while 3 other respondents stated otherwise. In the fourth statement, "Environmental conditions at home support children with special needs learning concentration", as many as 15 respondents agreed with the statement, while 5 other respondents stated otherwise. Then, as many as 19 respondents also agreed with the statement that "The school provides sufficient assistance to parents of student with special needs", only 1 respondent stated otherwise. In the last statement submitted, as many as 12 respondents agreed with the statement that "Beyond the current emergency situation, this learning process from home can be applied in the future", while 8 other respondents stated otherwise.

\subsection{Difficulties in Mentoring Children with special needs in Online Learning}

Results of parents' responses to difficulties in mentoring children with special needs in online learning are shown Table 4. As many as $70 \%$ of respondents find it difficult to accompany children with special needs to learn online because they have to provide funds to buy internet quotas every day. As many as $55 \%$ of respondents feel disturbed when doing work at home because they have to accompany children with special needs to learn online from home. But, this makes $75 \%$ of respondents still accompany their children with special needs to study while doing other homework. Then, $60 \%$ of respondents feel difficulties accompanying children with special needs to learn online because children with special needs learn at will not according to learning hours at school. Then, $60 \%$ of respondents feel 
that it is not difficult to accompany their children with special needs to learn online because they have internet access.

Table 3. Results of parental assistance response to children with special needs in online learning.

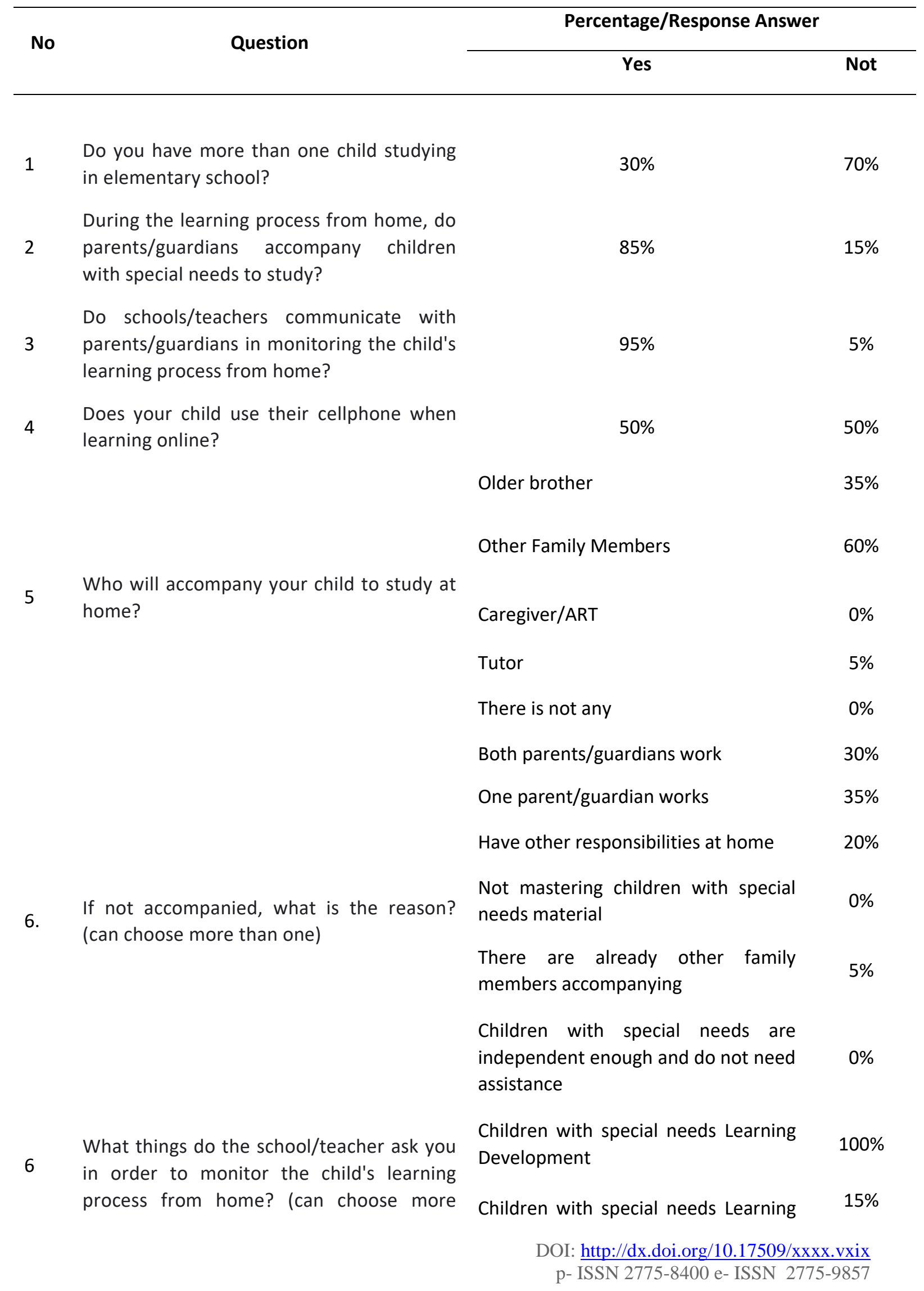


than one)

What do you do to monitor your child's learning activities from home? (can choose more than one)

\section{Motivation}

Children with special needs Learning Method

Children with special needs Learning Facilities and Resources

Completing the completion of tasks that children with special needs do

Checking the children with special needs work

Checking children with special needs understanding of learning materials

Communicating with children with special needs regarding learning difficulties

Consulting with teachers regarding children with special needs learning barriers

Not monitoring children with special needs learning activities

Mobile (HP)

$100 \%$

Wifi

Television $40 \%$

What electronic devices do you have at

8 home that can support online learning? (can choose more than one)

$$
\text { Lapto }
$$

Laptc

Computer

$\begin{array}{ll}\text { Camera } & 0 \%\end{array}$

Cam Recorder $\quad 0 \%$

$\begin{array}{ll}\text { Whatsapp } & 100 \%\end{array}$

Telegram $\quad 5 \%$

Youtube $\quad 55 \%$

What applications do you have on your mobile (HP)/laptop/computer to support online learning? (can choose more than one) 
What do you think about the following learning from home process?

\section{Answer Frequency}

Question

Agree

Do not

agree

My child can understand the subject matter well during the learning process from home

My child can use learning devices well (laptops, cellphones, learning applications, etc.)

My child uses media and offline learning resources well (TV, radio, worksheets,

printed teaching materials)

Environmental
conditions at home
support children with
special needs learning
concentration
The school provides
adequate assistance to
parents of student with
special needs
Outside of an emergency
situation like today, the
process of learning from
home like this can be
applied in the future

Environmental

conditions at home support children with 
return to study at school, this is indicated by the majority of respondents, $95 \%$ of them feel happier if their children with special needs study at school because that way, parents do not have the burden or obligation to accompany their children with special needs to study.

Table 4. Results of parents' responses to difficulties in mentoring children with special needs in online learning.

\begin{tabular}{|c|c|c|c|}
\hline \multirow[t]{2}{*}{ No } & \multirow[t]{2}{*}{ Question } & \multicolumn{2}{|c|}{$\begin{array}{l}\text { Percentage of } \\
\text { Answers }\end{array}$} \\
\hline & & Yes & Not \\
\hline 1 & $\begin{array}{l}\text { Do you find it difficult to accompany your child to learn online because they } \\
\text { have to provide funds to buy internet quota every day? }\end{array}$ & $70 \%$ & $30 \%$ \\
\hline 2 & $\begin{array}{l}\text { Are you disturbed when doing homework because you have to accompany } \\
\text { your child to learn online from home? }\end{array}$ & $55 \%$ & $45 \%$ \\
\hline 3 & $\begin{array}{l}\text { Do you find it difficult to accompany your child to learn online because } \\
\text { the child learns at will not according to school hours? }\end{array}$ & $60 \%$ & $40 \%$ \\
\hline 4 & $\begin{array}{l}\text { Are you having trouble accompanying your child to learn online because } \\
\text { you don't have internet access? }\end{array}$ & $40 \%$ & $60 \%$ \\
\hline 5 & $\begin{array}{l}\text { Do you find it difficult to teach your child to use a laptop or cellphone } \\
\text { (HP) to do the assignments given by the teacher? }\end{array}$ & $30 \%$ & $70 \%$ \\
\hline 6 & $\begin{array}{l}\text { Do you find it difficult to teach children with special needs to learn online } \\
\text { because sometimes the internet network is interrupted/disconnected? }\end{array}$ & $80 \%$ & $20 \%$ \\
\hline 7 & $\begin{array}{l}\text { Are you having a hard time teaching your kids to learn online because } \\
\text { homework is being neglected? }\end{array}$ & $60 \%$ & $40 \%$ \\
\hline 8 & $\begin{array}{l}\text { Do you get stressed when you have difficulty understanding the } \\
\text { assignments given by the teacher to children with special needs? }\end{array}$ & $45 \%$ & $55 \%$ \\
\hline 9 & $\begin{array}{l}\text { Are you sometimes emotional in accompanying your child to study } \\
\text { because the child is not disciplined in learning? }\end{array}$ & $90 \%$ & $10 \%$ \\
\hline 10 & $\begin{array}{l}\text { Do you prefer children with special needs to study at school because } \\
\text { there is no burden or obligation to accompany children with special needs } \\
\text { to study? }\end{array}$ & $95 \%$ & $5 \%$ \\
\hline 11 & $\begin{array}{l}\text { Do you prefer your child to study at home because you don't have to pay } \\
\text { for transportation? }\end{array}$ & $15 \%$ & $85 \%$ \\
\hline 12 & Do you accompany your child to study while doing other homework? & $75 \%$ & $25 \%$ \\
\hline 13 & Do you routinely accompany your child to learn online every day? & $85 \%$ & $15 \%$ \\
\hline
\end{tabular}


In line with the previous question item, $85 \%$ of respondents feel they are not happier when their children with special needs study at home, thus again implying that the majority of respondents hope that their children with special needs can go back to school even if they need to pay for transportation. However, due to the situation which also makes it impossible for children with special needs to return to school, $85 \%$ of respondents still routinely accompany children to learn online every day.

Broadly speaking, the results of this study are not much different from the problems in the implementation of learning carried out from home described above. Specifically, the obstacles experienced by parents in accompanying their children with special needs to study at home during the Covid-19 pandemic will be described below.

\subsubsection{Lack of material understanding by parents}

The results of the research in the field show that understanding the material by parents in accompanying children with special needs to study at home during this pandemic is an obstacle in its implementation. This is in line with previous research, which stated that during learning at home or online, many parents lacked understanding of the material provided by the school or teacher, parents considered the tasks given to be difficult so that they were difficult to convey to their children with special needs (Cahyati \& Kusumah, 2020).

The broad understanding of the material possessed by parents is very useful in helping children with special needs learn at home. Learning cannot be maximized if parents do not fully understand the material provided by the teacher to be taught to children with special needs, as revealed by previous research that parents must really master the learning material provided by the teacher so that home education can be successful (Irma et al., 2019).

Constraints on the lack of understanding of the material by parents are also called pedagogical obstacles, the forms of obstacles include, have never received training, have not experienced, and have not received assistance (Muhdi, 2020). The obstacles that have been mentioned related to the lack of understanding of the material by parents can be overcome or minimized by deliberation between parents and teachers, so that teachers can provide other alternatives to parents. Inputs from teachers are very useful to overcome the difficulties experienced by parents (Irhamna, 2016).

\subsubsection{Difficulties in cultivating children with special needs learning interest}

Cultivating children with special needs interest in learning is also an obstacle that is felt by parents while accompanying children with special needs to study at home during the Covid-19 pandemic. This is certainly a significant obstacle, given that building children with special needs motivation is a powerful way to shape children with special needs good academic results (Master \& Walton, 2013).

Expressing interest as a whole gives strength to learn, therefore the first thing that is important in learning is to cultivate interest in learning. Interest can also be interpreted as a tendency to pay attention and act towards a person, activity or situation that is the object of the interest accompanied by feelings of pleasure (Nofita, 2013). Taking into account these opinions, it can be concluded that fostering children with special needs interest in learning plays an important role in carrying out learning activities or learning activities. However, 
what parents face in assisting their children with special needs to study at home during the Covid-19 pandemic is different from what is expected.

In the learning process at home, children with special needs must experience anxiety, stress, sadness, boredom, boredom, and other feelings that reduce children with special needs interest in learning. For children with special needs like this, this is where the role of parents is needed so that children with special needs have self-regulating so that they are able to teach themselves in an effort to provide internal reinforcement. If the child has started building reinforcement within himself in accordance with the learning tasks he is undergoing, this will have a significant impact on the child (Subarto, 2020).

The strategy for parents to teach and build self-regulation, for children with special needs to develop behaviors that are released in order to have the ability to organize and plan their own learning process every day at home, among others what can be done is, discussing some rules in the house, giving directions to children with special needs about appropriate behavior, for example, is for children with special needs to get guidance for achievement, convey uncomplicated ways to children with special needs to solve problems related to the ability to maintain interpersonal relationships with teachers and classmates while at home, if the child shows emotional behavior, it shows how to overcome it and also how to explain the consequences of the behavior, be a friend, or a friend in sharing tasks related to selfregulation. For example, we can be as a friend to think about completing assignments and being a friend to ask questions. And, this must be a consistent process, preparing and showing real strategies to children with special needs in an effort to maintain their learning abilities (e.g. prepare and schedule children with special needs learning activities in detail so that they are easy to follow), prepare instructions on how best to study effectively (for example, give children with special needs questions and then ask children with special needs to give complete answers by reading books at home), provide opportunities for children with special needs to do complex tasks independently and of course parents need to prepare instructions that can be used as references for children with special needs, especially those who do not have the ability to organize learning activities independently before (Subarto, 2020).

\subsubsection{Difficulties in operating the gadget}

Difficulties in operating gadgets are also an obstacle faced by parents in accompanying children with special needs to study at home during the Covid-19 pandemic. This is in line with other research which states that in online learning, not all parents are able to operate gadgets because some parents are still not technology literate (Lestari \& Gunawan, 2020). Parents' low mastery of technology when learning online is also mentioned in a study conducted by Karnawati \& Mardiharto (2020). They argue that this is the most common obstacle encountered in online learning.

Given that in online learning, not all parents are able to operate gadgets, it is important to note that communication between parents and teachers is needed in this regard (Herliandry et al., 2020). Teachers can minimize the level of difficulty in using gadgets for parents who have complaints about the operation of gadgets. Teachers can provide student with special needs work via text messages to parents and help children with special needs to complete them. 


\subsubsection{Do not have enough time to accompany children with special needs to study at home because they have to work}

Parents do not have enough time to accompany their children with special needs to study at home because having to work is another problem during this Covid-19 pandemic. The role of parents is very important in the implementation of learning at home during the Covid-19 pandemic, because parents are the first educators for children with special needs in family education, therefore, parents must always try their best to guide children with special needs when studying at home (Irhamnna, 2016). Based on the results of the study, the obstacles faced by parents in nurturing their children with special needs are sometimes the lack of time people have due to busy working outside.

With the limited time that parents have to accompany their children with special needs to study at home, it should not be a barrier to family momentum and also the expectations of all of us in connection with circular letter number 4 of 2020 regarding the implementation of education policies in the emergency period of the spread of the corona virus disease (Covid-19). With the synergy from all parties on how to make everyone an educator and at the same time as a student with special needs, it is not impossible that this "learning from home" moment will run successfully even though it is constrained by time constraints (Subarto, 2020).

\subsubsection{Parents are impatient in accompanying children with special needs studying at home}

Many parents in accompanying children with special needs learning at home are impatient so that they get annoyed and take it out on their children with special needs. In fact, parents must be figures in giving patience to children with special needs, other things show that it turns out that parents also feel bored with learning done at home and the WFH that is applied, it triggers the impatience of parents in accompanying children with special needs to learn and play (Tabiin, 2020). Impatience is one of the mistakes in educating children with special needs, and in fact there are still many parents who are impatient in educating children with special needs, this is of course very unfortunate because parents have an obligation to shape, direct, guide, and educate children with special needs with great patience.

Indeed, parents must know that the child's psychological well-being, in the sense that the child does not become anxious or stressed in new situations (Tabiin, 2020). In this case, parents must take an attitude to formulate the handling of tantrums in children with special needs caused by boredom while studying at home, namely parents recognize the pattern of tantrums in children with special needs and minimize the occurrence of tantrums in children with special needs.

\subsubsection{Constraints related to internet service coverage}

Negative thing about internet services is that it can affect the health of student with special needs. Another obstacle found was the ability of parents to provide online educational facilities such as the use of the internet network which required no small amount of money. This condition appears to be different from that in China, which has been able to provide better supporting infrastructure for online learning in schools and universities. Since the last few decades, the Chinese government has built a number of 
national projects to prepare online learning infrastructure in schools and even create online school projects (Wang et al., 2009).

The obstacles faced by parents in assisting children with special needs to study at home during the Covid-19 pandemic as described, namely the lack of understanding of the material by parents, the difficulty of parents in cultivating children with special needs' learning interest, not having enough time to accompany their children with special needs because have to work, parents are impatient in accompanying children with special needs when studying at home, parents' difficulties in operating gadgets, and obstacles related to internet service coverage are expected in the future this will no longer be an obstacle in learning at home for children with special needs so that children with special needs are able to get good learning services optimal, because good and optimal service for children with special needs in learning is the main key in the success of learning objectives (Maryanti et al., 2020a; Maryanti et al., 2020b; Maryanti et al., 2020c).

\section{CONCLUSION}

In general, the obstacles for parents in accompanying their children with special needs to study at home during the Covid-19 pandemic are the lack of understanding of the material by parents, the difficulty of parents in growing their children with special needs interest in learning, not having enough time to accompany their children with special needs because they have to work, parents do not patient in accompanying children with special needs while studying at home, parents' difficulties in operating gadgets, and obstacles related to internet service coverage. This research is expected to be able to explore the obstacles of parents in accompanying children with special needs when studying at home so that this research can contribute to further research in exploring solutions to these problems.

\section{AUTHORS' NOTE}

The authors declare that there is no conflict of interest regarding the publication of this article. The authors confirmed that the paper was free of plagiarism.

\section{REFERENCES}

Ardiansyah, and Arda. (2020). Peran orang tua dalam proses belajar anak di masa pandemi covid-19 dalam menumbuhkan sikap ilmiah. Musawa, 12(1), 140-164.

Cahyati, N., and Kusumah, R. (2020). Peran orang tua dalam menerapkan pembelajaran di rumah. Jurnal Golden Age, 4(1), 152-159.

Harahap, S. A., Dimyati, D., and Purwanta, E. (2021). Problematika pembelajaran daring dan luring anak usia dini bagi guru dan orang tua di masa pandemi covid 19. Jurnal Obsesi: Jurnal Pendidikan Anak Usia Dini, 5(2), 1825-1836.

Herliandry, L. D., Nurhasanah, N., Suban, M. E., and Kuswanto, H. (2020). Pembelajaran pada masa pandemi covid-19. JTP-Jurnal Teknologi Pendidikan, 22(1), 65-70. 
Iftitah, S. L., and Anawaty, M. F. (2020). Peran orang tua dalam mendampingi anak di rumah selama pandemi Covid-19. Journal of Childhood Education, 4(2), 71-81.

Irhamna. (2016). Analisis kendala yang dihadapi orang tua dalam menanamkan akhlak dan kedisiplinan belajar siswa Madrasah Darussalam Kota Bengkulu. Pembelajaran Alquran Hadis di Man Pagar Alam, 3(6), 57-65.

Irma, C. N., Nisa, K., \& Sururiyah, S. K. (2019). Keterlibatan orang tua dalam pendidikan anak usia dini di TK Masyithoh 1 Purworejo. Jurnal Obsesi: Jurnal Pendidikan Anak Usia Dini, 3(1), 214-224.

Karnawati, K., and Mardiharto, M. (2020). Sekolah Minggu Masa Pandemi Covid 19: Kendala, Solusi, Proyeksi. Didache: Journal of Christian Education, 1(1), 13-24.

Lestari, A., and Gunawan. (2020). The impact of covid-19 pandemic on learning implementation of primary and secondary school levels. Indonesian Journal of Elementary and Childhood Education, 1(2) 58-63.

Master, A., and Walton, M. G. (2012). Minimal groups increase young children's motivation and learning on group-relevant tasks. Child Development, 84(2), 737-751.

Maryanti, R., Hufad, A., Sunardi, S., Nandiyanto, A. B. D., and Al-Obaidi, A. S. M. (2020a). Understanding covid-19 particle contagion through aerosol droplets for students with special needs. Journal of Engineering Science and Technology, 15(3), 1909-1920.

Maryanti, R., Nandiyanto, A. B. D., Manullang, T. I. B., Hufad, A., and Sunardi. (2020b). Adsorption of dye on carbon microparticles: physicochemical properties during adsorption, adsorption isotherm and education for students with special needs. Sains Malaysiana, 49(12), 2949-2960.

Maryanti, R., Hufad, A., Tukimin, S., Nandiyanto, A. B. D., and Manullang, T. I. B. (2020c). The importance of teaching viscosity using experimental demonstration from daily products on learning process especially for students with special needs. Journal of Engineering Science and Technology, 15, 19-29.

Nurkolis, N., and Muhdi, M. (2020). Keefektivan kebijakan e-learning berbasis sosial media pada PAUD di masa pandemi Covid-19. Jurnal Obsesi: Jurnal Pendidikan Anak Usia Dini, 5(1), 212-228.

Nofita, A. (2013). Hambatan - hambatan warga belajar dalam proses pembelajaran program paket c di Kecamatan Pancung soal Kabupaten Pesisir Selatan. SPEKTRUM: Jurnal Pendidikan Luar Sekolah, 1(1), 144-160.

Putra, R., and Irwansyah, I. (2020). Media komunikasi digital, efektif namun tidak efisien, studi media richness theory dalam pembelajaran jarak jauh berbasis teknologi di masa pandemi. Jurnal IImu Sosial dan Politik, 1(2), 1-13.

Subarto. (2020). Momentum keluarga mengembangkan kemampuan belajar peserta didik di tengah wabah pandemi Covid-19. ADALAH: Buletin Hukum dan Keadilan, 4(1), 13-18.

Tabiin. (2020). Problematika stay at home pada anak usia dini ditengah pandemi. Jurnal Golden Age, 4(1), 90-200. 
Wang, Q., Zhu, Q., Chen , L., and Yan, H. (2009). E-learning in China. Campus-Wide Information Systems, 26(2), 77-12.

Wardani, A., and Ayriza, Y. (2020). Analisis kendala orang tua dalam mendampingi anak belajar di rumah pada masa pandemi Covid-19. Jurnal Obsesi: Jurnal Pendidikan Anak Usia Dini, 5(1), 772-782. 